\title{
Characteristics and Geographical Distribution of Fiddleback Figure in Wood of Acer pseudoplatanus L. in Slovenia
}

\section{Obilježja i geografska rasprostranjenost gorskog javora (Acer pseudoplatanus L.) s valovitim vlakancima u Sloveniji}

\author{
Original scientific paper • Izvorni znanstveni rad \\ Received-prispjelo: 23. 12. 2014. \\ Accepted-prihvaćeno: 20. 5. 2015. \\ UDK: $630 * 113 ; 630 * 812.11 ; 674.031 .772 .224 .3$ \\ doi:10.5552/drind.2015.1447
}

\begin{abstract}
The wavy grain of wood expressed in fiddleback figure usually enhances its commercial value. The goal of this study was to analyse fiddleback figure and other log characteristics in sycamore maple (Acer pseudoplatanus $L$.) and their contribution to the price of the timber. We studied sycamore maple logs at the annual auction of the highest quality wood assortments in Slovenj Gradec, Slovenia. Measurements were performed on the logs and wavy grain was analysed in 2013. In addition, data were used on logs auctioned between 2007 and 2012. Using the data collected at the auction in 2013 and a binary logistic regression model, the original sample was expanded considerably. The percentage of fiddleback maple was $7.4 \%$ at the auction in 2013. Larger volume of maple logs was on average linked to higher price; however, the presence of fiddleback figure in a log per se did not guarantee above average price. Prices of more than half of the fiddleback figured maple logs at the auction in 2013 were below average. On the other hand, large fiddleback logs achieved the highest prices. Trees with fiddleback figure proved to be evenly distributed throughout the entire population of sycamore maple in Slovenia. The geographic origin of sycamore maple did not influence the occurrence of fiddleback figure. The presented results appear to be representative of the occurrence of fiddleback figure in Acer pseudoplatanus throughout its entire distribution range.
\end{abstract}

Key words: fiddleback figure, wavy grain, sycamore maple (Acer pseudoplatanus), commercial value, origin, Slovenia

SAŽETAK • Valovitost vlakanaca drva obično povećava komercijalnu vrijednost drva. Cilj provedenih istraživanja bio je analizirati valovitost vlakanaca i druga obilježja gorskog javora (Acer pseudoplatanus L.) te njihov

\footnotetext{
${ }^{1}$ Authors are student and professor at University of Ljubljana, Biotechnical Faculty, Department of Forestry and Renewable Forest Resources, Ljubljana, Slovenia. ${ }^{2}$ Author is professor at University of Ljubljana, Biotechnical Faculty, Department of Wood Science and Technology, Ljubljana, Slovenia.

' Autori su student i profesor Sveučilišta u Ljubljani, Biotehnički fakultet, Odjel šumarstva i obnovljivih šumskih resursa, Ljubljana, Slovenija. ${ }^{2}$ Autorica je profesorica Sveučilišta u Ljubljani, Biotehnički fakultet, Odjel za znanost o drvu i drvnu tehnologiju, Ljubljana, Slovenija.
} 
doprinos cijeni drva. Proučavani su trupci gorskog javora ponuđeni na godišnjoj dražbi najkvalitetnijih drvnih sortimenata u Slovenj Gradecu u Sloveniji. Mjerenja na trupcima i analiza valovitosti vlakanaca provedeni su 2013. godine. Osim toga, u radu se navode i analiziraju i podaci o trupcima koji su bili na aukciji između 2007. i 2012. godine. Korištenjem podataka prikupljenih na aukciji 2013. godine i primjenom binarnoga logističkog regresijskog modela izvorni je uzorak znatno proširen. Na aukciji 2013. godine postotak javorovih trupaca s valovitim vlakancima iznosio je 7,4\%. Veći obujam trupaca javora po pravilu je povezan s višim cijenama trupaca. Međutim, valovitost vlakanaca ne jamči iznadprosječnu cijenu trupca. Na aukciji 2013. godine više od polovice trupaca s valovitim vlakancima imalo je cijenu nižu od prosječne. Nasuprot tome, veliki trupci s valovitošću vlakanaca postigli su najviše cijene. Stabla gorskog javora s valovitim vlakancima ravnomjerno su raspoređena u cijeloj populaciji gorskog javora u Sloveniji. Zemljopisno podrijetlo gorskog javora nije utjecalo na pojavu valovitosti vlakanaca. Prikazani rezultati mogu se smatrati reprezentativnima za pojavu valovitosti vlakanaca $u$ stabala gorskog javora u cijelom njegovu arealu.

Ključne riječi: valovita tekstura drva, valovitost vlakanaca, gorski javor (슬 pseudoplatanus), komercijalna vrijednost, podrijetlo, Slovenija

\section{INTRODUCTION}

\section{UVOD}

Axial elements in wood are normally oriented more or less parallel to the tree axis, which is called straight grain. Deviations from straight grain, such as spiral or wavy grain, are fairly common. Wavy (also curly) grain results from waves in the direction of the grain with respect to the longitudinal axis of the tree (Figure 1a). Split faces of such logs show waves on the radial or tangential faces (Panshin and de Zeeuw, 1980). Wavy grain in the wood of different tree species is considered to be a desirable "natural defect", as it often greatly enhances the commercial value of the timber. Such grain can be observed locally or over the entire tree stem (Harris, 1989). The distinctive pattern can be observed on the longitudinal radial surface as a series of alternately bright and dark stripes shading into one another and thus producing the illusion of waves (Beals and Davis, 1977). The resulting pattern of wavy grain can be seen on boards (or veneer) and is called fiddle back figure (Figure 1b).

Wavy grain is commonly found near the limbs and roots, localized in small areas in many tree species. Well-developed wavy grain resulting in fiddleback figure is rare in trees of most species (Bucur, 2006; Harris, 1989; Beals and Davis, 1977). Nevertheless, fiddleback figure is frequently observed in maple (Acer), ash (Fraxinus), birch (Betula), and walnut (Juglans) (Harris, 1989; Beals and Davis, 1977; Pillow 1955). The beauty of the wavy grain structure is often the most important criterion when selecting among fiddleback maples, but commercially valuable wood rarely occurs in trees with diameters less than $25 \mathrm{~cm}$ (Beals and Davis, 1977).

Sycamore maple or sycamore (Acer pseudoplatanus L.) wood with fiddleback figure, also known as fiddleback maple, curly maple or tiger maple, is often used for furniture and musical instruments for its favourable decorative and acoustic properties. Historically, the term "fiddleback" comes from the extensive use of such wood for the back plates, ribs, necks, and scrolls of stringed instruments such as violins and guitars (Figure 1b). It is not only decorative, but it is also considered a resonance wood in terms of its acoustic properties (Beals and Davis, 1977; Bucur, 2006).
Since the occurrence of fiddleback figure in maple is relatively infrequent, regular non-figured maple wood is often worth considerably less than that figured. Rieder (1998) reports that the presence of fiddleback figure in maple increases wood value from $150 \%$ to $200 \%$. Sycamore maple assortments have consistently achieved the highest prices among wood assortments over the last ten years. The highest prices have also seen a constant increase (e.g., Kobal et al., 2013). Analysis of the data from log auctions that took place from 2007 to 2014 in Slovenj Gradec, Slovenia, showed that fiddleback maple consistently achieves significantly higher prices than any other wood. Most of the auctioned wood was bought for use by instrument makers in Western Europe (Krajnc, 2013).

The exact percentage of maple trees with fiddleback figure in the entire population is unknown. Some authors report that fiddleback figure occurs in $3 \%$ of the sycamore maple population (Rieder, 1998; Conrad, 1957), while others estimate its frequency at $4 \%$ (Maurer, 1982) or $6 \%$ (Wedel, 1964). All authors suggest that wavy grain in maple is heritable, but there are apparently no reliable research results confirming this. Walters (1951), for instance, reported that Juglans nigra L. with wavy grain could be propagated by grafting. Later research disputed these results (MacDaniels, 1953). Recently, Aubakirova and Kalashnikova (2011) have developed a useful technology for clonal micropropagation of curly birch. Fan et al. (2013) experimented on curly aspen and concluded that figure in aspen wood can be genetically heritable. However, according to the current state of knowledge, grain orientation does not seem to be governed by simple genetic regulation. Consequently, there are no commercial plantations of fiddleback maple and no methods for producing figured wood or artificially inducing its occurrence.

The occurrence of fiddleback figure in wood also seems to be independent of soil type, climate, geographical position or any other known factor. Most of the best figured wood develops in well formed, straight and healthy trees. Tree size also has little effect on figure. The best developed figure occurs in the outer areas of tree stems, outside of the inner juvenile zone (Beals and Davis, 1977). Due to grain deviations, fiddleback figured wood has a lower modulus of elasticity and compressive strength in the axial direction and higher 
longitudinal shrinkage compared to straight-grained wood (Vintoviv, 1981; Wedel, 1964).

Beals and Davis (1977) noted that, in general, forests in certain geographical areas produced more fiddleback figured trees than others. However, to our knowledge there has been no detailed research on the possible geographical distribution of fiddleback figure in sycamore maple in Europe.

As valuable maple trees with fiddleback figure are scarce in forests, scientists have often been motivated either to find a wood species to substitute fiddleback maple or to provide a means to detect wavy grain in standing trees (Bucur, 2006). Such detection is possible using various methods. Wavy grain in Acer can be detected to some degree by removing bark and examining the wood underneath (Beals and Davis, 1977; Pillow, 1955). Wave lengths in fiddleback maple range between 0.7 and $2.0 \mathrm{~cm}$, reaching a maximum height near $0.3 \mathrm{~cm}$. However, the expression of the waves is often more obvious on the radial split face than on the tangential surface below the bark.

Furthermore, non-destructive detection of wavy grain in maple is claimed to be possible by using ultrasound. This method is based on measuring the time of ultrasound transition through the wood, as its velocities significantly differ in trees with wavy grain and in those without it. In fiddleback maple the velocities are generally higher than in normal wood. Literature reports suggest that differences in velocity can also be caused by very abundant radially oriented rays (Bucur, 2005; Bucur, 1987).

The lack of recent studies on the formation of fiddleback figure can be ascribed to difficulties arising from its rarity, scattered spatial distribution, and long-term processes of its accumulation. Some aspects were studied some decades ago on relatively small sample sizes (Wedel, 1964; Vintoviv, 1981). Knowledge on its formation can therefore be considered fragmentary, making it difficult to generalize about larger populations. However, ongoing advances in genetics and various non-destructive detection methods could offer new possibilities to investigate the occurrence of fiddleback maple.

To our knowledge, there is also a lack of reports on the apparently stable relationship between fiddleback figure and higher timber prices, and on the possible existence of a predetermined geographic distribution of fiddleback occurrence in the sycamore maple population.

The aim of this study was, therefore, to elucidate the relationship between wavy grain / fiddleback characteristics expressed on the surface of sycamore maple $\log$ s and the influence of various measurable log characteristics on their prices. The origin of the logs was also studied to discover whether there exists any predetermined geographic distribution.

\section{MATERIAL AND METHODS}

\section{MATERIJAL I METODE}

The study was carried out at a timber yard during the annual auction of the highest quality wood assort-

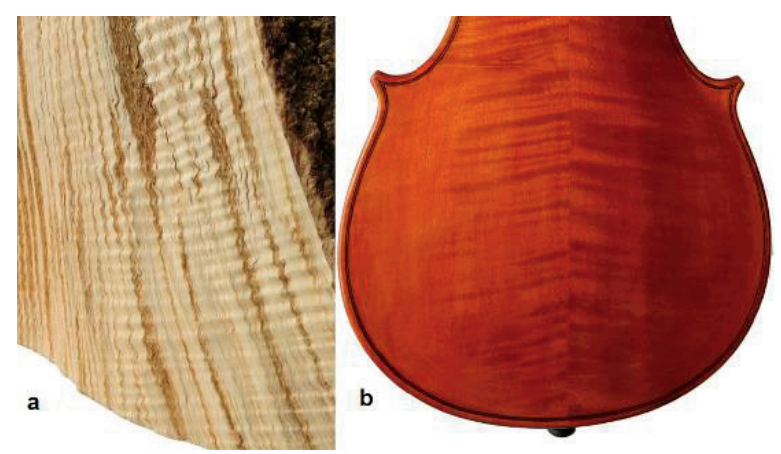

Figure 1 (a) Wavy grain on split radial surface of wood and (b) the back plate of a violin made from fiddleback maple Slika 1. (a) Valovitost vlakanaca na radijalnoj površini drva; (b) leđa violine izrađena od drva javora valovitih vlakanaca

ments in Slovenj Gradec, Slovenia, in 2013. The data collected in 2013 were enhanced with available data from auctions held at the same location from 2007 to 2012. The auctions are open for any participant, either as a seller or a buyer. Every year the sellers, mainly Slovenian forest owners, transport their logs to the auction site, where all logs are measured and numbered by the company organizing the auction. Afterwards, potential buyers inspect the logs on site and give individual offers for those they are interested in purchasing. After the auction closes, all offers are collected and for each of the logs the highest offer wins. In this way, price negotiations between buyers and sellers are avoided. Each year, a large portion of the logs belonged to the genus Acer, specifically to Acer pseudoplatanus.

First, we investigated all sycamore maple (Acer pseudoplatanus) logs in the 2013 auction. For analysis, each log was divided into three parts, and on each of them a randomly placed sample plot was defined, sized approximately $210 \mathrm{~cm}^{2}(21 \mathrm{~cm} \times 10 \mathrm{~cm})($ Figure 2$)$. The bark was removed from each plot and the wood beneath was examined for signs of wavy grain, as proposed by Beals and Davis (1977). If wavy grain was identified, three waves were randomly selected and their lengths and heights measured. Three random pairs of adjacent waves were selected and the distances between the pairs were measured. In this way the number of waves on the $210 \mathrm{~cm}^{2}$ surface $(21 \mathrm{~cm} \times 10 \mathrm{~cm})$ was recorded. Each measurement was repeated at least twice to reduce the effect of human error. All wave heights and lengths were measured with a Vernier caliper with a precision of 0.01 $\mathrm{mm}$. The average wave length was calculated from the number of waves per plot.

If the wavy grain was present in at least one of the three plots, a strip of bark was removed along the whole length of the log and the total length of the portion with wavy grain was measured. If no signs of wavy grain were found on any of the three sample plots, no further measurements were conducted on that particular log.

The orientation of the wavy grain varied among the logs. About one third of the logs exhibited wavy grain on the radial surface (Figure 1a); therefore, the inspected surface of the log (i.e. tangential surface of 


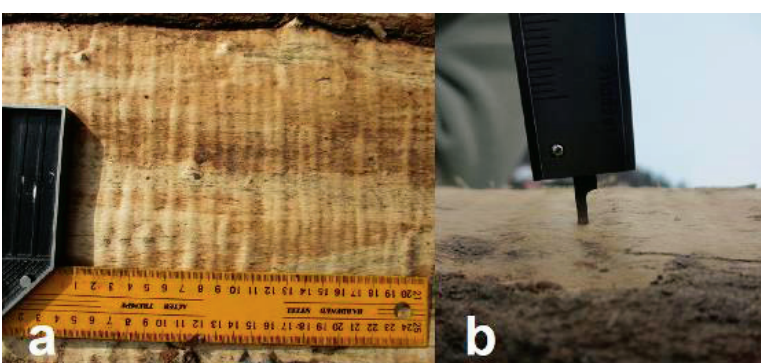

wave length

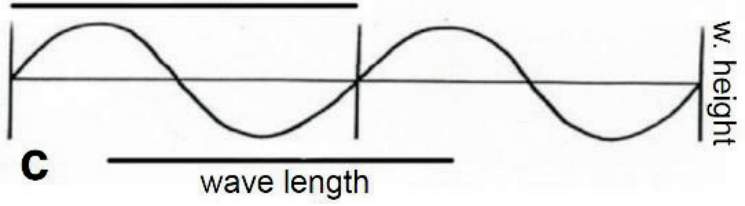

Figure 2 (a) Sample plot $(21 \mathrm{~cm} \times 10 \mathrm{~cm})$ on the log, where the bark was removed, (b) height measurement of the waves and (c) measured wave characteristics

Slika 2. (a) Uzorak trupca s valovitim vlakancima na mjestu gdje je skinuta kora; (b) mjerenje visine valova; (c) mjerena obilježja valova

the wood) was flat. Such logs were analysed as well, but the wave heights could not be measured.

The following data were also collected for all the logs at the 2013 auction: log dimensions (length, mid diameter), $\log$ grade (based on five quality-based categories ranging from veneer (best quality) to sawn wood (lowest quality)), as well as price offers and the final price achieved for each log. Similar data were also obtained for the auctions held from 2007 to 2012. In this case the data included log dimensions, log grade, price achieved per log and per cubic meter, number of offers received per $\log$ and residence (address) of each individual seller.

The data from the 2007-2012 auctions allowed us to expand the 2013 data set by using binary logistic regression.

After digitalization of the recorded data, the normality of the distribution was checked for each recorded numeric variable using the Kolmogorov-Smirnov test. Comparisons between sampled variables were made using different methods (Mann-Whitney $U$ or Analysis of variance) depending on the normality and homogeneity of variances in different variables by using SPSS (IBM, 2012). Correlations between them were estimated using Spearman's rank correlation coefficient.

Using the 2013 auction data and binary logistic regression, a model was developed to predict the probability of wavy grain occurrence in any sycamore maple log based on its mid diameter, volume, achieved price per cubic meter and per log, number of offers received and log grade. Log grade entered the regression as a categorical value. Since the model was used for the logs of the previous auctions, all the data which entered the regression were standardized to avoid shortcomings deriving from different data distributions in previous auctions.

As the predicted probability of wavy grain in a $\log$ was not sufficient to conduct further analysis, a bi- nary classifier was employed to assign each log into one of two categories - wavy grain present (1) / not present $(0)$. The threshold of the probabilistic classifier was determined using an ROC curve (Curk et al., 2006). The threshold of probability between the two categories was set to 0.192 as our binary classifier had optimal classification accuracy there. Our classifier was accurate in $93.5 \%$ of cases, which was considered satisfactory for further use.

Using the data from the 2007-2012 auctions, the original sample of $31 \operatorname{logs}$ was expanded with wavy grain in the 2013 auction to $199 \operatorname{logs}$, and the number of all included sycamore maple logs was increased from 417 to 3184 .

Each of the logs was assigned an area of its probable origin in Slovenia. This was estimated based on the location of the owner's residence with 10-kilometre radius buffer zone. The assumption on log origin was based on previous research of Slovenian forest owner characteristics (Medved, 2000; Oršanič, 2005; Oršanič, 2007; Žepič, 2010) showing that over $95 \%$ of the private forest properties in Slovenia were located within a radius of 10 kilometres around the owners' residence. To this purpose, each residence location was geocoded and the coordinates were used to prepare maps of probable log origin in ArcGis. Due to frequent overlap of the areas, maps of relative densities of probable origin were made for easier interpretation.

\section{RESULTS}

\section{REZULTATI}

Logs with wavy grain / fiddleback figure and those without it showed no statistically significant differences in dimensions (length, mid diameter), grades and minimal price offers. On the other hand, the prices per $\mathrm{m}^{3}$ and per log, as well as the number, mean and sum of the offers (Table 1) were significantly different for the logs with fiddleback grain compared to those without it. Fiddleback maple achieved higher prices on average with a larger range and different distribution (higher coefficients of variation and larger standard deviations). The differences can be attributed to a higher number and variance of the offers for fiddleback maple. The comparisons between fiddleback and regular maple apply to data from the 2013 auction only, as there are no reliable sources differentiating the two groups in previous years. However, the data from 2013 were deemed reliable as each of the logs was inspected individually.

No significant differences were found in wavy grain characteristics of logs having waves on the tangential or radial surface (Table 2). Maximum wave height (amplitude) was $1.6 \mathrm{~mm}$, measured wave lengths ranged from 4 to $13.26 \mathrm{~mm}$, and the calculated wave lengths ranged from 7.5 to $52.5 \mathrm{~mm}$.

No significant correlations were found between the variables related to the number and length of waves, length of logs and portion with fiddleback figure, volume, prices and number of received offers. However, the achieved price per log moderately correlated with the absolute length of the portion of detected wavy 
Table 1 Differences between maple logs with (1) and without (0) wavy grain / fiddleback figure (auction 2013). The differences are significant if $p<0.05$ (Mann-Whitney $\mathrm{U}$ )

Tablica 1. Razlike između javorovih trupaca s valovitim vlakancima (1) i bez valovitosti (0); razlika je značajna ako je $p<0,05$ (Mann-Whitneyjev U-test)

\begin{tabular}{|c|c|c|c|c|c|c|}
\hline \multicolumn{3}{|l|}{ Variable / Varijabla } & $\begin{array}{l}\text { Asymp. Sig. } \\
\text { (2-tailed) }\end{array}$ & $\begin{array}{c}\text { Mean } \\
\text { Srednja }\end{array}$ & $\begin{array}{c}\text { St. dev } \\
\text { Stand. dev. }\end{array}$ & $\begin{array}{l}\text { Range } \\
\text { Raspon }\end{array}$ \\
\hline \multirow{2}{*}{$\begin{array}{l}\text { Price per } \mathrm{m}^{3}(€) \\
\text { cijena po } m^{3}(€)\end{array}$} & \multirow{2}{*}{ Fiddleback f. present } & 0 & \multirow{2}{*}{.000} & 206.0 & 281.7 & 3440.0 \\
\hline & & 1 & & 1160.5 & 1519.9 & 6121.0 \\
\hline \multirow{2}{*}{$\begin{array}{l}\text { Price per } \log (€) \\
\text { cijena po trupcu }(€)\end{array}$} & \multirow{2}{*}{ Fiddleback f. present } & 0 & \multirow{2}{*}{.000} & 219.8 & 371.0 & 3073.6 \\
\hline & & 1 & & 1411.5 & 2382.1 & 11881.2 \\
\hline \multirow{2}{*}{$\begin{array}{l}\text { Number of offers } \\
\text { broj ponuda }\end{array}$} & \multirow{2}{*}{ Fiddleback f. present } & 0 & \multirow{2}{*}{.000} & 3.0 & 1.0 & 8.0 \\
\hline & & 1 & & 4.0 & 3.0 & 10.0 \\
\hline \multirow{2}{*}{$\begin{array}{l}\text { Offer mean }(€) \\
\text { prosjek ponuda }(\epsilon)\end{array}$} & \multirow{2}{*}{ Fiddleback f. present } & 0 & \multirow{2}{*}{.000} & 133.3 & 107.6 & 899.4 \\
\hline & & 1 & & 467.2 & 619.3 & 3069.3 \\
\hline \multirow{2}{*}{$\begin{array}{l}\text { Offer sum }(€) \\
\text { zbroj ponuda }(\epsilon)\end{array}$} & \multirow{2}{*}{ Fiddleback f. present } & 0 & \multirow{2}{*}{.000} & 473.3 & 730.4 & 7142.5 \\
\hline & & 1 & & 3361.3 & 7064.3 & 37387.0 \\
\hline \multirow{2}{*}{$\begin{array}{l}\text { Coefficient of variation (\%) } \\
\text { koeficijent varijacije }(\%)\end{array}$} & \multirow{2}{*}{ Fiddleback f. present } & 0 & \multirow{2}{*}{.000} & 28.8 & 25.2 & 176.5 \\
\hline & & 1 & & 62.0 & 40.9 & 155.3 \\
\hline
\end{tabular}

Table 2 Means and standard deviations of measured wave characteristics (fiddleback maple, 2013)

Tablica 2. Srednje vrijednosti i standardne devijacije izmjerenih obilježja valovitosti vlakanaca

\begin{tabular}{|l|c|c|}
\hline Variable / Varijabla & $\begin{array}{c}\text { Mean } \\
\text { Srednja vrijednost }\end{array}$ & $\begin{array}{c}\text { St. dev. } \\
\text { Stand. devijacija }\end{array}$ \\
\hline $\begin{array}{l}\text { Average measured number of waves per plot, mm } \\
\text { prosječan broj izmjerenih valova na mjernoj površini, } m m\end{array}$ & 16.75 & 4.78 \\
\hline Average measured wave length, mm / prosječna izmjerena duljina vala, $\mathrm{mm}$ & 13.26 & 2.42 \\
\hline Average measured wave height, mm / prosječna izmjerena visina vala, $\mathrm{mm}$ & 0.51 & 0.33 \\
\hline Average calculated wave length per log, mm / prosječna izračunata duljina vala, $\mathrm{mm}$ & 14.45 & 7.58 \\
\hline
\end{tabular}
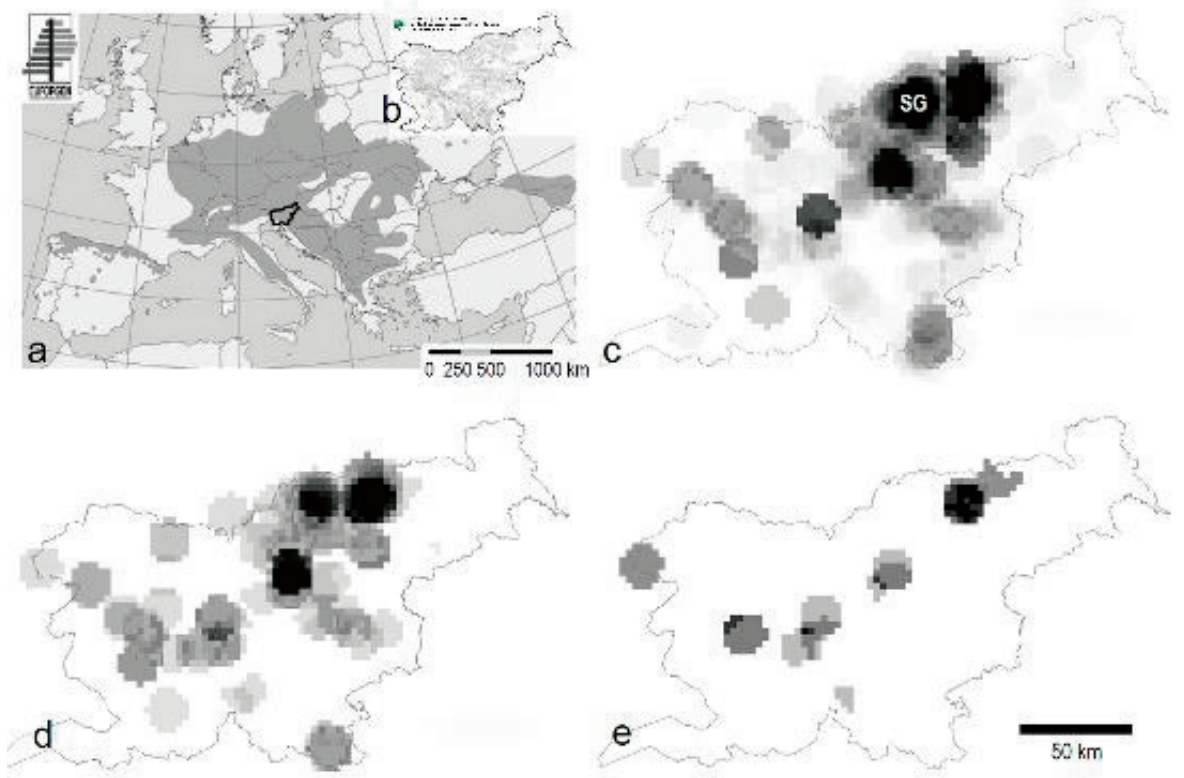

Figure 3 Distribution of sycamore maple (Acer pseudoplatanus) in (a) Europe and (b) Slovenia, and maps of Slovenia with (c) relative densities of probable origin of all sycamore maple logs from the 2007-2013 auctions in Slovenj Gradec (SG) $(n=3121)$, (d) relative densities of probable origin of expanded fiddleback maple samples from the 2007-2013 auctions $(\mathrm{n}=199)$ and (e) relative densities of probable origin of fiddleback maple at the 2013 auction $(\mathrm{n}=31)$. Distribution maps of sycamore maple (Acer pseudoplatanus) in Europe (EUFORGEN, 2009) and in Slovenia (Pisek 2010, Zavod za gozdove Slovenije)

Slika 3. Rasprostranjenost gorskog javora (Acer pseudoplatanus) u (a) Europi i (b) Sloveniji; (c) karte Slovenije s relativnom gustoćom vjerojatnosti podrijetla svih trupaca gorskog javora koji su bili na aukciji u razdoblju 2007. - 2013. u Slovenj Gradecu (SG) ( $n=3121)$, (d) relativna gustoća vjerojatnosti podrijetla gorskog javora s valovitošću vlakanaca u proširenom uzorku s aukcijom iz razdoblja 2007. - 2013. godine $(n=199)$; (e) relativna gustoća vjerojatnosti podrijetla gorskog javora s valovitošću vlakanaca u uzorku s aukcije 2013. godine $(n=31)$. Karte rasprostranjenosti gorskog javora (Acer pseudoplatanus) u Europi (EUFORGEN, 2009.) te u Sloveniji (Pišek, 2010., Zavod za gozdove Slovenije). 
Table 3 Differences between sycamore maple prices of the group (1) achieving above mean (above s. m.) and (2) below mean (below s. m.) prices of fiddleback maple (auction 2013). In all cases differences are statistically significant (MannWhitney $\mathrm{U} ; \mathrm{p}<0.05$ )

Tablica 3. Razlike između cijena javorovih trupaca s valovitim vlakancima koji postižu iznadprosječnu (above s. m.) (1) i ispodprosječnu cijenu (below s. m.) (2) (uzorak trupaca s aukcije 2013. godine); razlike su značajne u svim slučajevima (Mann-Whitneyjev U-test; $p<0,05$ )

\begin{tabular}{|c|c|c|c|c|c|c|c|}
\hline Variable / Varijabla & & $\begin{array}{c}\text { Asymp. } \\
\text { Sig. } \\
\text { (2-tailed) }\end{array}$ & $\mathbf{N}$ & $\begin{array}{c}\text { Mean } \\
\text { Srednja } \\
\text { vrijed. }\end{array}$ & $\begin{array}{c}\text { Median } \\
\text { Medi- } \\
\text { jan }\end{array}$ & $\begin{array}{l}\text { Modus } \\
\text { Modus }\end{array}$ & $\begin{array}{c}\text { St. } \\
\text { dev. }\end{array}$ \\
\hline \multirow{2}{*}{$\begin{array}{l}\text { Average number of waves per log } \\
\text { prosječan broj valova po trupcu }\end{array}$} & Below s. m. & \multirow{2}{*}{.030} & 16 & 13.5 & 13.3 & 9.0 & 5.5 \\
\hline & Above s. m. & & 15 & 17.7 & 16.7 & 14.0 & 3.2 \\
\hline \multirow{2}{*}{$\begin{array}{l}\text { Maximum number of waves per log } \\
\text { najveći broj valova po trupcu }\end{array}$} & Below s. m. & \multirow{2}{*}{.041} & 16 & 14.8 & 14.5 & 9.0 & 6.6 \\
\hline & Above s. m. & & 15 & 19.3 & 19.0 & 14.0 & 4.4 \\
\hline \multirow{2}{*}{$\begin{array}{l}\text { Minimum number of waves per log } \\
\text { najmanji broj valova po trupcu }\end{array}$} & Below s. m. & \multirow{2}{*}{.021} & 16 & 12.2 & 12.0 & 9.0 & 5.1 \\
\hline & Above s. m. & & 15 & 16.1 & 16.0 & 14.0 & 2.6 \\
\hline \multirow{2}{*}{$\begin{array}{l}\text { Mean calculated wave length }(\mathrm{mm}) \\
\text { prosječna vrijednost izračunate duljine valova }(\mathrm{mm})\end{array}$} & Below s. m. & \multirow{2}{*}{.028} & 16 & 19.7 & 16.1 & 23.3 & 11.9 \\
\hline & Above s. m. & & 15 & 12.3 & 13.1 & 15.0 & 2.1 \\
\hline \multirow{2}{*}{$\begin{array}{l}\text { Log length }(\mathrm{m}) \\
\text { duljina trupca }(\mathrm{m})\end{array}$} & Below s. m. & \multirow{2}{*}{.046} & 16 & 4.0 & 4.0 & 2.5 & 1.3 \\
\hline & Above s. m. & & 15 & 5.7 & 6.0 & 3.4 & 2.3 \\
\hline \multirow{2}{*}{$\begin{array}{l}\text { Length of fiddleback figure on } \log (\mathrm{m}) \\
\text { duljina valovite teksture na trupcu }(\mathrm{m})\end{array}$} & Below s. m. & \multirow{2}{*}{.004} & 16 & 2.2 & 1.7 & 3.0 & 1.6 \\
\hline & Above s. m. & & 15 & 4.1 & 3.9 & 2.3 & 2.0 \\
\hline \multirow{2}{*}{$\begin{array}{l}\text { Percentage of log length with f.f. (\%) / postotak duljine } \\
\text { trupca na kojemu se nalaze valovita vlakanca (\%) }\end{array}$} & Below s. m. & \multirow{2}{*}{.031} & 16 & 53.2 & 41.7 & 100.0 & 27.2 \\
\hline & Above s. m. & & 15 & 74.7 & 66.7 & 100.0 & 26.9 \\
\hline \multirow{2}{*}{$\begin{array}{l}\text { Volume }\left(\mathrm{m}^{3}\right) \\
\text { volumen }\left(\mathrm{m}^{3}\right)\end{array}$} & Below s. m. & \multirow{2}{*}{.005} & 16 & 0.7 & 0.7 & 0.5 & 0.3 \\
\hline & Above s. m. & & 15 & 1.2 & 1.1 & 0.5 & 0.5 \\
\hline \multirow{2}{*}{$\begin{array}{l}\text { Price per cubic meter }(€) \\
\text { cijena po kubičnome metru }(€)\end{array}$} & Below s. m. & \multirow{2}{*}{.000} & 16 & 146.1 & 142.0 & 127.0 & 51.8 \\
\hline & Above s. m. & & 15 & 2242.6 & 1718.0 & 411.0 & 1586.4 \\
\hline \multirow{2}{*}{$\begin{array}{l}\text { Price per } \log (€) \\
\text { cijena po trupcu }(€)\end{array}$} & Below s. m. & \multirow{2}{*}{.000} & 16 & 109.8 & 112.2 & 13.6 & 57.2 \\
\hline & Above s. m. & & 15 & 2800.0 & 2080.7 & 263.5 & 2855.5 \\
\hline \multirow{2}{*}{$\begin{array}{l}\text { Number of received offers } \\
\text { broj primljenih ponuda }\end{array}$} & Below s. m. & \multirow{2}{*}{.000} & 16 & 2.9 & 3.0 & 3.0 & 0.7 \\
\hline & Above s. m. & & 15 & 6.1 & 5.0 & 4.0 & 2.8 \\
\hline
\end{tabular}

grain $(\rho=0.541, p<0.01)$, the achieved price per cubic meter with relative (percentage of log length) length of the detected portion of wavy grain $(\rho=0.448, p<0.05)$ and $\log$ volume with achieved price per cubic meter $(\rho=0.571, p<0.01)$.

Prices of more than a half (51\%) of the sycamore maple logs at the auction in 2013 with fiddleback figure were below average. Differences between the two groups achieving below and above average prices are listed in Table 3; all of them are significant.

Comparison of the means of the measured characteristics of wavy grain showed no significant differences between plot location on the stem and parameter means. If wavy grain is present, homogeneity of its characteristics can be expected.

Finally, three maps were constructed of the relative densities of the probable origin of fiddleback sycamore maple in Slovenia within its natural range (Figure $3 \mathrm{a}, \mathrm{b})$. They show the most probable origin of all sycamore maple logs auctioned in Slovenj Gradec between 2007 and 2013 (Figure 3c), the origin evaluated based on the expanded sample (2007-2013) obtained with binary logistic regression (Figure $3 \mathrm{~d}$ ), and the origin of the logs auctioned in 2013, which served as a control (Figure 3e).

The distribution in Figure $3 \mathrm{e}$ is very similar to the one in Figure 3d; therefore, it may be concluded that the method used can be considered adequate for further comparisons.

\section{DISCUSSION}

4. RASPRAVA

The measured characteristics expressed on the outer surface of individual logs are fairly homogenous in a particular log; thus, in future research there is no need to increase the number of plots per log to measure wavy grain characteristics. It also appears that it is not necessary to measure fiddleback characteristics along the whole length of its appearance.

Contrary to the general consensus, the sole presence of fiddleback figure in a log does not guarantee that its price will be above average. The logs with fiddleback figure that had above average prices were as a rule longer, had greater diameters and volumes, and had a larger portion of wavy grain and a higher number of waves per $\log$ (Table 3 ). As such, the sole presence of wavy grain/fiddleback figure did not prove to be sufficient to increase the value of the log. Higher prices were only achieved when the $\log$ had a sufficient amount and quality of wavy grain.

As seen on the presented maps, relative densities of sycamore maple log origin show multiple local and one regional culmination. The regional maximum can be observed in the proximity of Slovenj Gradec, where the auctions were held. The higher density around Slovenj Gradec is probably due to the higher participation rate of local forest owners since they have lower transport costs. They are also better informed and mo- 
tivated to attend the auction compared to owners from other areas in Slovenia. Nevertheless, local culminations are not evenly distributed throughout the country. They agree well with the general distribution of the sycamore maple population in Slovenia (Figure 3b), which shows that different habitats are suitable for this species. To a lesser extent, some local culminations could also be a result of the regular participation of the same owners or owner associations in the auctions, which is also related to their awareness and motivation. Comparison of the map in Figure $3 \mathrm{c}$ with those in Figures $3 \mathrm{~d}$ and $3 \mathrm{e}$ shows no notable differences between geographic origin or concentration of sycamore maple with or without fiddleback figure. Based on this, it can be concluded that the occurrence of fiddleback figure in sycamore maple trees is not locally limited or conditional. Fiddleback figure is apparently evenly distributed in the entire sycamore maple population and is probably not directly affected by environmental factors. As our research was conducted over a relatively large geographic area and included a large sample, the general findings can also be applied to the wider geographic area within the general distribution range of sycamore maple (EUFORGEN, 2009).

Since there is a lack of notable research on the spatial distribution and characteristics of fiddleback maple, it is difficult to compare the data from Slovenia with those of other areas. The percentage of sycamore maple trees with expressed fiddleback figure among all auctioned sycamore maple logs was $7.4 \%$ at the auction in 2013, slightly more than the 3-6\% reported by Rieder (1998), Conrad (1957), and Wedel (1964). However, log selection could have led to biased observations given that presumably only the most valuable logs were selected for auction. On the other hand, most owners, when selecting the logs for auction, hope that they are of high quality but due to lack of knowledge and detection methods in standing trees, they often cannot exactly estimate whether fiddleback figure is present in the selected logs or not. Due to this, one could argue that the sycamore maples at the auction are, nevertheless, more or less randomly selected out of the general sycamore maple population, and that as such, the analysed sample is suitable for drawing general conclusions.

Current biotechnology knowledge and sylvicultural measures do not make it possible to induce wavy grain or to manipulate its characteristics in sycamore maple at this moment. However, this is not the case for log volume, as one can generally influence tree age at felling. Larger log volumes proved to be linked to higher prices, so early selection of fiddleback trees as crop trees and releasing them with tending or specially cultivating them would likely pay off considerably. Bearing this in mind, it would make sense to invest more resources for further research into the non-destructive detection of wavy grain in standing trees.

The results of this study indicate recommended directions of future research. Since fiddleback figure seems to occur regularly through space and time, there could be a common cause or trigger that has yet to be discovered. To study wavy grain and fiddleback figure in situ, reliable non-destructive methods of its detection in standing trees are needed. The use of ultrasound seems promising, but further research is needed to validate this or other non-destructive methods through different sycamore maple subpopulations. As we are not aware of any current ongoing research on the development of wavy grain and the factors influencing it, this topic appears to remain relatively unexplored.

\section{CONCLUSION \\ 5. ZAKLJUČAK}

Inspection of sycamore maple logs at the auction of the highest quality wood assortments in Slovenj Gradec in 2013 showed that the percentage of fiddleback maple was $7.4 \%$. This is slightly more than reported by other studies, mainly because logs of above average quality were selected for auction.

The presence of fiddleback figure in a log per se did not guarantee above average price. Higher price was mainly affected by larger log diameters and volumes.

Trees with fiddleback figure proved to be evenly distributed throughout the entire population of sycamore maple in Slovenia. The results appear to be representative of the occurrence of fiddleback figure in Acer pseudoplatanus throughout its distribution range.

\section{Acknowledgments - Zahvale}

This research was financially supported by the Pahernik Foundation, the Slovenian Research Agency (ARRS), research programmes P4-0059 and P4-0015, and the Ministry of Agriculture, Forestry and Food and ARRS, project V4-1419. We thank Primož Grudnik for supplying log data from auctions 2007-2013 and gratefully acknowledge the technical assistance of Andraž Poljšak. We thank Rok Pisek for help with the map and Jan Nagel for language editing.

\section{REFERENCES}

6. LITERATURA

1. Aubakirova, L. S.; Kalashnikova, E. A., 2011: Experimental morphogenesis in a curly birch tissue culture. Plant Industry, 37 (2): 15-16.

http://dx.doi.org/10.3103/S1068367411020030

2. Beals, H.; Davis, T., 1977: Figure in wood - an illustrated review. Auburn, Alabama. Auburn University, Agricultural experiment station.

3. Bucur, V., 2006: Acoustics of wood, 2nd ed. SpringerVerlag, Berlin.

4. Bucur, V., 2005: Ultrasonic techniques for nondestructive testing of standing trees. Ultrasonic, 43: 237-239. http://dx.doi.org/10.1016/j.ultras.2004.06.008

5. Bucur, V., 1987: Wood characterization through ultrasonic waves. In: Alippi, A., Mayer, W. G. (eds.). Ultrasonic methods in evaluation of inhomogeneous materials. NATO ASI Ser E Appl Sci no 126. Nijhoff, Dordrecht, pp. 323-342.

http://dx.doi.org/10.1007/978-94-009-3575-4_23 
6. Conrad, J., 1957: Plusbaumauswahl unter besonderer Berücksichtigung der Holzqualität. Forstarchiv, 28 (7): 133137.

7. Curk ,T.; Vuk, M., 2006: ROC curve, lift chart and calibration plot. Advances in Methodology and Statistics, 3 (1): 89-108.

8. Fan, Y.; Rupert, R.; Wiedenhoeft, A. C.; Woeste, K.; Lexer, C.; Meilan, R., 2013: Figured grain in aspen is heritable and not affected by graft-transmissible signals. Trees - Structure and Function, 27 (4): 973-983. http://dx.doi.org/10.1007/s00468-013-0849-1

9. Harris, J. M., 1989: Spiral grain and wave phenomena in wood formation. Berlin, Springer-Verlag Berlin Heidelberg New York. http://dx.doi.org/10.1007/978-3-642-73779-4

10. Kobal, M.; Kristan, S.; Grudnik, P.; Vilhar, U., 2013: Supply and demand at auctions of value wood assortments in Slovenj Gradec. Gozdarski Vestnik, 71 (10): 462-470.

11. Krajnc, L., 2013: Rebrasta tekstura v lesu gorskega javorja (Acer pseudoplatanus L.) = Fiddleback figure in wood of sycamore maple (Acer pseudoplatanus L.): B. Sc. Thesis. University of Ljubljana, Biotechnical Faculty, Department of Forestry and Renewable Forest Resources. Ljubljana.

12. MacDaniels, L. H., 1953: Some aspects of the problem of producing curly-grained walnut. In: Proceedings of the 44th annual report of the northern nut growers association, Rochester.

13. Maurer, E., 1982: Der Ahorn. In: Bäume und Wälder in Bayern. Bayerischer Forstverein, W. Ludwig Verlag: 17-21.

14. Medved, M., 2000: Consequences of property structure on forest management in Slovenian small scale private forests: dissertation thesis. University of Ljubljana, Biotechnical Faculty, Department of Forestry and Renewable Forest Resources. Ljubljana.

15. Oršanič, T. H., 2005: Conservation of nature and forest ownership - a case study of Posavje area: M.Sc.Thesis University of Ljubljana, Biotechnical Faculty, Department of Forestry and Renewable Forest Resources. Ljubljana.

16. Oršanič, T. H., 2007: Ohranjanje narave v zasebnih gozdovih Posavja. Varstvo narave, 20: 35-50.

17. Panshin, A.; De Zeeuw, C., 1980: Textbook of wood technology. New York, Mc Graw-Hill.
18. Pillow, M. Y., 1955: Detection of figured wood in standing trees. Research Paper No. 2034. USDA Forest Service, Forest Products Laboratory, Madison.

19. Pisek, R., 2010: Distribution of sycamore maple (Acer pseudoplatanus) in Slovenia. Zavod za gozdove Slovenije, Oddelek za gozdno gospodarsko načrtovanje. http:// www.zgs.si/fileadmin/zgs/main/img/CE/gozdovi_SLO/ Karte/Gorski_javor_2.JPG

20. Rieder, A., 1998: Āhorn-Wertholzproduktion in kurzen Umtrieben. AFZ, Der Wald, 15: 776-779.

21. Vintoniv, I. S., 1981: Some physical and mechanical properties of wavy-grain wood of sycamore maple. Lesnoi Zhurnal, 6: 56-58.

22. Walters, C. S., 1951: Figured walnut propagated by grafting. Journal of Forestry, 49: 917.

23. Wedel, K., 1964: Untersuchungen über Eigenschaften, Verwertung und Verwendung des Ahornholzes: Diss. Göttingen, Forstl. Fak. Univ. Göttingen.

24. Žepič, V., 2010: Presoja možnosti za uvajanje načrtov za zasebno gozdno posest na Gozdnogospodarskem območju Kranj = The evaluation of possibilities for introduction of private forest property plans in the Kranj forest management region: graduation thesis. University of Ljubljana, Biotechnical Faculty, Department of Forestry and Renewable Forest Resources. Ljubljana.

25. *** EUFORGEN, 2009: Distribution map of Sycamore (Acer pseudoplatanus). www.euforgen.org

26. *** IBM Corp. Released 2012. IBM SPSS Statistics for Windows, Version 21.0. Armonk, NY: IBM Corp.

\section{Corresponding address:}

\section{Professor ROBERT BRUS, Ph.D.}

University of Ljubljana

Biotechnical Faculty

Department of Forestry and Renewable Forest

Resources

Jamnikarjeva 101

SI-1000 Ljubljana, SLOVENIA

e-mail: robert.brus@bf.uni-lj.si 